Bp Piotr Turzyński ${ }^{1}$

\title{
Zasada wewnętrzności w myśli świętego Augustyna
}

Święty Augustyn z Hippony przeszedł długą drogę nawrócenia i przemiany od niespokojnego serca goniącego za zewnętrznym przemijającym pięknem do zachwytu Najwyższym Pięknem, które znaleźć można w głębi swego wnętrza i u podstaw wszystkiego, co istnieje. Na jego rozwój psychiczny, intelektualny i duchowy wpływ miało spotkanie z neoplatonizmem i ze świętym Ambrożym, przebyty czas sceptycyzmu, świadectwo życia mnichów w Egipcie, ale także doświadczenie estetyczne i przemyślenia dotyczące tej dziedziny ludzkiej aktywności². Odkrycie świata duchowego, do którego odsyłał świat materialny, oraz odkrycie Boga niewidzialnego, ukrytego głęboko w duszy, przemieniało jego wizję świata. Osobiście doświadczył, że kluczową rolę w życiu człowieka odgrywa zasada wewnętrzności. Hans Urs von Balthasar zauważa, że nawrócenie Augustyna to przejście od estety do człowieka religijnego. Mówi też, że jest to nawrócenie od estetyki wspólnej wszystkim do estetyki głębszej i wyższej³ . Po nawróceniu kontemplacja zewnętrznego piękna przekształciła się u Augustyna w kontemplację mistyczną tego,

\footnotetext{
1 Bp dr hab. Piotr Turzyński, adiunkt w Katedrze Patrologii Greckiej i Łacińskiej w Instytucie Historii Kościoła i Patrologii na Wydziale Teologii Katolickiego Uniwersytetu Lubelskiego Jana Pawła II; e-mail: pturzynski@episkopat.pl; ORCID: 0000-0002-3493-5184.

2 Por. J. Tscholl, Dio e il bello in sant'Agostino, Milano 1996, s. 9.

3 Por. H.U. von Balthasar, Chwała. Estetyka teologiczna, t. 2: Modele teologiczne, cz. 1: Od Ireneusza do Bonawentury, Kraków 2007, s. 93.
} 
co niewidzialne. On sam opisuje swoje nawrócenie, używając do tego kategorii estetycznych. Mówi o pięknie Boga i swojej brzydocie:

Późno Cię umiłowałem, Piękności tak dawna a tak nowa, późno Cię umiłowałem. W głębi duszy byłaś, a ja się błąkałem po bezdrożach i tam Ciebie szukałem, biegnąc bezładnie ku rzeczom pięknym, które stworzyłaś. Ze mną byłaś, a ja nie byłem z Tobą. One mnie więziły z dala od Ciebie - rzeczy, które by nie istniały, gdyby w Tobie nie były. Zawołałaś, rzuciłaś wyzwanie, rozdarłaś głuchotę moją. Zabłysnęłaś, zajaśniałaś jak błyskawica, rozświetliłaś głuchotę moją. Rozlałaś woń, odetchnąłem nią - i oto dyszę pragnieniem Ciebie. Skosztowałem - i oto głodny jestem, i łaknę. Dotknęłaś mnie - i zapłonąłem tęsknotą za pokojem Twoim ${ }^{4}$.

Augustyn znajduje Boga w „głębi duszy”, a Agostino Trapè zauważa, że od tej pory wewnętrzność należy do podstawowych zasad myśli augustyńskiej ${ }^{5}$. Warto zobaczyć, że ta zasada wewnętrzności nie ma bynajmniej tylko wymiaru filozoficznego i posiada kluczowe znaczenie w spojrzeniu na całą rzeczywistość.

\section{Inventio i elocutio ${ }^{6}$. Wewnętrzność w retoryce i w teorii znaków}

Augustyn nie napisał podręcznika do retoryki, ale otrzymał gruntowane wykształcenie retora, a potem jego zadaniem podstawowym przed nawróceniem było uczenie sztuki mówienia. W wielu dziełach formułował krytyczne uwagi co do złego użycia retoryki. Zauważał, że niektórzy

4 Augustinus, Confessiones 10, 27, 38, CSEL 33/1, s. 255, tł. J. Kubiak, Święty Augustyn, Wyznania, Warszawa 1987, s. 246.

5 Por. A. Trapè, Sant'Agostino, w: Patrologia, t. 3, red. A. di Berardino, Marietti 1978, s. 386.

6 Zob. Rhetorica ad Herennium 1, 2, 3; Quintilianus, Institutio oratoria 3, 3, 12. 
ludzie pełni hipokryzji i pychy posługują się tą sztuką dla niskich i fałszywych celów ${ }^{7}$.

Retoryka dla Herenniusza, najstarsze rzymskie dzieło poświęcone retoryce przypisywane przez długi czas Cyceronowi, wyróżnia pięć działów sztuki mówienia. To są równocześnie pewne umiejętności wymagane od retora. Inventio jest to zdolność odnajdowania tematów i argumentów, prawdziwych i ważnych, bądź też prawdopodobnych, o których warto mówić i które przekonują do postawionej tezy. Drugim działem jest dispositio. Jest to zdolność porządkowania argumentów i twierdzeń według logiki i mądrej oraz zrozumiałej sekwencji. Trzecią częścią retoryki jest elocutio, tzn. umiejętność dobrania odpowiednich słów i figur retorskich adekwatnych do tematu, ale także do zdolności percepcyjnych słuchaczy. Ostatnie dwa działy dotyczą pamięci (memoria) i pronuncjacji (pronuntiatio $)^{8}$.

Augustyn w młodości był pod wielkim wpływem ideału retora i pragnął zdobyć umiejętność błyskotliwego przemawiania. Po lekturze Hortenzjusza Cycerona zrodziła się w nim miłość do mądrości. W dialogu O porządku przyznaje, że retoryka ma jedynie rolę pomocniczą w stosunku do filozofii, która jest właśnie miłością mądrości ${ }^{9}$. W Wyznaniach powie, że nauczyciele retoryki podawali mu w naczyniach pięknych słów „wino kłamstwa"10, a potem on, ponieważ panowało w nim pożądanie pieniędzy, sprzedawał innym ,tę sztukę, która miała im umożliwić panowanie nad przeciwnikami w dyskusjach [...] w celu ocalenia winnego od wyroku"11. Forma i słowa były ważniejsze od treści, elocutio liczyła się bardziej niż inventio. Augustyńska wrażliwość poruszona łaską nie mogła tego wytrzymać.

7 Por. Augustinus, Confessiones 1, 16, 26, CSEL 33/3, s. 24; 5, 6, 11, CSEL 33/3, s. 97; 12, 26, 36, CSEL 33/3, s. 337.

8 Por. B. Mortara Garavelli, Manuale di retorica, Milano 1988, s. 59.

Zob. Augustinus, De ordine 2, 13, 38, CC 29, s. 98.

10 Augustinus, Confessiones 1, 16, 26, CSEL 33/3, s. 24.

11 Augustinus, Confessiones 4, 2, CSEL 33/3, s. 64. 
Idąc za myślą Arystotelesa przekazaną mu przez Cycerona, po nawróceniu Augustyn podkreśla, że trzeba połączyć elokwencję z mądrością ${ }^{12}$. Retoryka nadaje formę i użycza środków, które mają służyć prawdzie.

Prawdą jest, że przy pomocy sztuki oratorskiej można przekazywać zarówno prawdę, jak i fałsz. Kto więc ośmieli się twierdzić, że prawda powinna zostawić bezbronnymi swoich obrońców w obliczu kłamstwa? Jakżeż to? Tamci mówcy, wysilający się, żeby wmówić fałsz, potrafią zaraz na wstępie zdobyć życzliwość i uwagę słuchaczy, gdy, przeciwnie, obrońcy prawdy mieliby temu nie podołać? Pierwsi mieliby przedstawić swoje błędy zwięźle, jasno, z wielką dozą prawdopodobieństwa, drudzy natomiast ukazywać prawdę tak, by stała się niemiła przy słuchaniu, niełatwa w zrozumieniu, a wreszcie żeby było trudno w nią uwierzyć? ${ }^{13}$.

Augustyn retor dowartościowuje zewnętrzną formę, ale każe jej służyć prawdzie. Rozpoznając wartość retoryki jako sztuki mówienia, Augustyn dokonuje pewnej weryfikacji i korekty akcentów. Sztuka retorska wpływa na sposób komunikowania (elocutio) tego, co jest prawdą i zostało przyjęte rozumem oraz sercem. Jednak treść przekazu płynąca z inventio posiada tu swoje niezaprzeczalne pierwszeństwo. Waga i piękno prawdy, jej wewnętrzna siła, decyduje w stopniu największym o pięknie i znaczeniu jej zewnętrznego wyrażenia. W młodości Augustyn pogardził Biblią z powodu jej niskiej, jak wówczas myślał, kultury retorskiej, ale potem będzie podkreślał, że chociaż autorzy biblijni mogli nie znać zasad retoryki, to jednak „mądrości towarzyszy elokwencja”14.

Warto zauważyć, że u Augustyna pojawia się nowy typ semiotyki, w której znaki nie są tylko symptomami jakiegoś fenomenu empirycz-

12 Por. N. Cipriani, Retorica, w: Agostino. Dizionario enciclopedico, red. A.D. Fitzgerald - L. Alici - A. Pieretti, Roma 2007, s. 1204.

13 Augustinus, De doctrina cristiana 4, 2, 3, CC 32, s. 142, tł. J. Sulowski, Święty Augustyn, O nauce chrześcijańskiej, Warszawa 1989, s. 181.

14 Augustinus, De doctrina cristiana 4, 7, 11, CC 32, s. 144. 
nego, ale raczej są zewnętrznymi ekspresjami rzeczywistości wewnętrznej ${ }^{15}$. Według niego słowa i gesty są znakami zewnętrznymi wnętrza człowieka, wskazują na myśli serca ${ }^{16}$. Również koncepcja sakramentu jest opisana według matrycy z tej nowej teorii znaku. Sakramenty są więc znakami zewnętrznymi i widzialnymi wewnętrznej łaski. Augustyn porusza się w platońskiej wizji świata, gdzie świat materialny jest manifestacją rzeczywistości głębszej. Znaki posiadają więc walor objawiający, a cała rzeczywistość ma charakter symboliczny ${ }^{17}$. W teorii znaków Augustyn rozróżnia znak (signum) i rzecz oznaczaną (res), a sztuka polega na przekazaniu za pomocą znaku tego, co jest treścią i prawdą. Na tej podstawie w Wyznaniach napisze, że dusza „opierając się na Twoich stworzeniach wznosi się ku Tobie" 18 i artykułuje zasadę, która prowadzi we wszystkich dziedzinach poznania i mądrości: per corporalia ad incorporalia ${ }^{19}$.

\section{Wewnętrzność $w$ teorii poznania i metafizyce}

Nawrócony Augustyn napisze ,w człowieku wewnętrznym mieszka prawda"20. W starożytnym świecie, zwłaszcza w nurcie platońskim, filozofowanie najczęściej rozpoczyna się wezwaniem do powrotu do siebie samego. Dla Augustyna prawda jest czymś wewnętrznym, a zarazem przewyższa umysł i nie jest dotykalna zmysłami. Jego refleksja nie zatrzymuje się na podmiocie, idzie dalej i wyżej, wstępuje ku temu, co transcenduje człowie-

15 Por. Ph. Cary, Interiorità, w: Agostino. Dizionario enciclopedico, red. A.D. Fitzgerald - L. Alici - A. Pieretti, Roma 2007, s. 846.

16 Por. Augustinus, De Trinitate 15, 11, 20, CC 50, s. 482.

17 Por. E.J. Curtone, Sacramenti, w: Agostino. Dizionario enciclopedico, red. A.D. Fitzgerald - L. Alici - A. Pieretti, Roma 2007, s. 1232.

18 Augustinus, Confessiones 5, 1, 1, CSEL 33/1, s. 79, tł. J. Kubiak, s. 85.

19 Augustinus, Retractationes 1, 3, 1, CSEL 36/2, s. 2: ,,per corporalia cupiens ad incorporalia quibusdam quasi passibus certis vel pervenire vel ducere".

20 Augustinus, De vera religione 39, 72, CC 32, s. 234, tł. J. Ptaszyński, Augustyn, O prawdziwej wierze, w: Św. Augustyn, Dialogi filozoficzne, Kraków 1999, s. 788. 
ka. W Wyznaniach Augustyn następująco zwraca się do Boga: „Ty byłeś bardziej wewnątrz mnie niż to, co we mnie było najbardziej osobiste, a zarazem wyżej nade mną, niż mogłem myślą sięgnąć kiedykolwiek"21. Prawdę można dosięgnąć ludzkim rozumem i jest ona uniwersalna, obiektywna i konieczna, przez co jest nieodwoływalna ${ }^{22}$. To właśnie umysł ludzki jest powiązany z rzeczywistością intelektualną i niezmienną. Dowodem tego dla Augustyna są aksjomaty matematyczne, podstawowe prawa moralne, reguły rozumowania. „To bowiem, że trzy razy trzy daje dziewięć, musi być prawdą, nawet gdyby cały ludzki ród chrapał"23. Przypadkiem szczególnym tej nieodwołalnej prawdy jest świadomość własnego istnienia. „Jeśli tedy jestem, skoro się mylę, to jak mogę się mylić w tym, że jestem"24. To jest augustyńskie zwycięstwo nad sceptycyzmem.

Idea wewnętrzności u biskupa z Hippony nie ma tylko znaczenia psychologicznego czy duchowego, ale przede wszystkim znaczenie metafizyczne. Tu rodzą się trzy podstawowe tematy filozofii augustyńskiej: ukazanie istnienia Boga, dowód na duchowość duszy i dowód na jej nieśmiertelność. W dialogu $O$ nauczycielu Augustyn przedstawia swoją teorię poznania, prezentując ją jako iluminację, oświecenie przez prawdę, która mieszka we wnętrzu człowieka, w rozumie i sercu. „W sprawie wszystkich rzeczy, które rozumiemy, radzimy się nie słów rozbrzmiewających na zewnątrz, lecz Prawdy, która wewnątrz nas kieruje samym umysłem" $" 25$.

Miłość mądrości każe Augustynowi wchodzić głębiej w tajemnice świata, rozumieć więcej i lepiej. W dialogu De musica podejmuje po-

21 Augustinus, Confessiones 3, 6, 11, CSEL 33/3, s. 53, tł. J. Kubiak, s. 52.

22 Por. A. Trapè, Sant'Agostino, w: Patrologia, t. 3, red. A. di Berardino, Marietti 1978, s. 386.

23 Augustinus, Contra academicos 3, 11, 25, PL 32, 947, tł. K. Augustyniak, Augustyn, Przeciw akademikom, w: Św. Augustyn, Dialogi filozoficzne, Kraków 1999, s. 130.

${ }^{24}$ Augustinus, De civitate Dei 11, 26, CC 48, s. 423, tł. ks. W. Kubicki, Święty Augustyn, Państwo Boże, Kęty 1998, s. 431. Por. Augustinus, De beata vita 2, 7, PL 32, 981.

25 Augustinus, De magistro 11, 38, CC 29, s. 173, tł. J. Modrzejewski, Augustyn, O nauczycielu, w: Św. Augustyn, Dialogi filozoficzne, Kraków 1999, s. 477. 
szukiwania dotyczące natury przedmiotu pięknego, rozpoczynając od rzeczy materialnych i przechodząc do rzeczy duchowych ${ }^{26}$. Cała rzeczywistość ma charakter uporządkowany i hierarchiczny, dlatego istnieje obowiązek wstępowania od tego, co niskie, do tego, co wyższe, od tego, co materialne, do tego, co duchowe, i od tego, co zewnętrzne, do tego, co wewnętrzne. „Przypatrz się pięknu kształtnego ciała - widzisz liczby w przestrzeni. Spójrz w piękne ruchy ciała - to liczby działają w czasie. A wejdź w samą sztukę, która ujęła w liczbę te zjawiska. Wznieś się więc jeszcze ponad duszę artysty, a zobaczysz odwieczną liczbę. Już teraz rozbłyśnie ci mądrość z samego wnętrza swej siedziby, z tajemniczego sanktuarium prawdy"27. Człowiek nie może zostać na powierzchni, ponieważ odnajduje radość i satysfakcję w przekraczaniu świata materialnego, zmysłowego i zewnętrznego. Zasadą wędrówki rozumu i duszy jest przejście od rzeczy materialnych, zmysłowych do niematerialnych i duchowych, które zajmują wyższe miejsce w hierarchii bytów. Równocześnie rzeczy niższe posiadają w sobie jakiś blask rzeczy wyższych.

Mówiąc o Maryi, Augustyn zauważa, że tak jak światło lampy umieszczone wewnątrz domu widoczne jest także na zewnątrz, tak piękno Maryi nie było niczym innym, tylko odbiciem ducha i wyrażeniem świętości. W taki sposób to, co wewnętrzne, objawia się i decyduje o tym, co piękne zewnętrznie. Maryja, jako pełna łaski, posiadała także piękno objawione na zewnątrz, to bowiem, co jest w środku i co jest ukryte głęboko, jaśnieje także na zewnątrz ${ }^{28}$.

Dla Augustyna wewnętrzny świat człowieka ostatecznie decyduje o jego duchowej wartości. Przykładem jest Hiob, który na zewnątrz ubogi, wewnątrz jest bogaczem. Augustyn zachęca swoich słuchaczy.

26 Por. E. Chapman, Saint Augustine's Philosophy of Beauty, New York - London 1939, s. 13.

27 Augustinus, De libero arbitrio 2, 16, 42, CC 29, s. 232, t1. A. Trombala, Augustyn, O wolnej woli, w: Św. Augustyn, Dialogi filozoficzne, Kraków 1999, s. 568-569.

28 Por. Augustinus, De doctrina cristiana 4, 21, 48, CC 32, s. 157. 
Jeżeli pragniecie być bogatymi, pożądajcie takich skarbów, z których nawet podczas rozbicia okrętu nic utracić nie możecie. [Chrześcijanie] mają z czego cieszyć się wewnętrznie. Ich władca jest wewnętrzny, ich pasterz i ich pocieszyciel. Biedni są ci, którzy nadzieję swą pokładają w tym świecie. Tracą to, co błyszczało na zewnątrz, a wewnątrz nie pozostaje nic poza zgryzotą złego sumienia. Nie znajdują w niczym pociechy, nie mają gdzie wyjść na zewnątrz i nie mają dokąd wrócić wewnątrz, opuściła ich chwała światowa, pozbawieni zostali łaski duchowej, prawdziwie zostali upokorzeni ${ }^{29}$.

Zewnętrzność i wewnętrzność są ze sobą powiązane. Zewnętrzność jest pewną formą, w którą ubrana jest wewnętrzność. Zewnętrzność potrafi człowieka zatrzymać na sobie. Dla Augustyna jednak byłoby tragedią zewnętrzności nie pokazać na głębszą treść i nie poprowadzić wyżej. W takim ujęciu to, co dotykalne zmysłami, materialne i zewnętrznie, nie traci swojego znaczenia, ale jest drogą prowadzącą w głąb, do rzeczy duchowych, wyższych i ostatecznie decydujących o wyjątkowości człowieka. Zasadą staje się droga od wiedzy do mądrości ${ }^{30}$. W Chrystusie i przez Chrystusa to powiązanie zewnętrzności i wewnętrzności realizuje się w przejściu od Jego człowieczeństwa do Jego bóstwa ${ }^{31}$.

\section{Ciało i dusza. Wewnętrzność w antropologii}

Według starożytnych filozofów człowiek składa się z dwóch elementów: duszy i ciała, które razem tworzą go jako nierozdzielną całość. W De Trinitate Augustyn pisze: ,człowiek jest substancją rozumną złożoną z duszy i ciała i nie ulega wątpliwości, że człowiek posiada duszę

29 Augustinus, Enarrationes in Psalmos 30 (4), 12, CC 38, s. 221, tł. J. Sulowski, Święty Augustyn, Objaśnienia Psalmów, PSP 37, Warszawa 1986, s. 268.

30 Zob. J.A. Doull, Qui es la sapientia augustiniana, AugM 36 (1991) s. 81-88.

31 Por. G. Madec, Christus, scientia et sapientia nostra. Le principe de cohérence de la doctrine augustinienne, RAug 10 (1975) s. 77-85. 
niebędącą ciałem oraz ciało, które nie jest duszą"32. Te dwa elementy istotowo różne, bo należące do innych sfer, tworzą nierozdzielną całość istoty ludzkiej. Bóg stworzył człowieka, obdarzając go od początku wewnętrzną harmonią między duszą i ciałem. To dopiero nieposłuszeństwo i samowola człowieka zburzyły harmonię wewnętrzną, zamykając człowieka w nieuporządkowanej miłości własnej33.

Ciało, chociaż podległe zmianom, cierpiętliwe i niedoskonałe, łączy człowieka ze światem materii, posiada jednak wielką godność. Zostało dowartościowane przez wcielenie Bożego Syna i w wieczności po zmartwychwstaniu ciało będzie „przyjacielem człowieka”34. Czeka je więc wielka przyszłość. Ciało nie jest przeznaczone do pogardy i zniszczenia. Jest darem, tak samo jak dusza. Jednak ważniejsza w człowieku jest dusza i ona należy do wyższego porządku i posiada piękno wyższego rzędu. Augustyn zauważa: „Nieszczęsna to dusza, jeżeli od ciała oczekuje rady. Ciało posłuszne, jak należy, jest sługą duszy. Ona rządzi, ono jest rządzone; ona rozkazuje, ono służy"35. Autor Wyznań odwołuje się zasady estetyki starożytnej, która głosi, że piękno duszy jest większe niż piękno ciała $^{36}$. W jednym z kazań Augustyn opowiada o dwóch sługach. Jeden z nich zewnętrznie nie jest atrakcyjny, ale zawsze wierny, drugi natomiast jest piękny fizycznie, ale wewnętrznie zły. Biskup pyta, który z nich posiada większą wartość i który będzie bardziej kochany. Odpowiedź wydaje się oczywista. „Rzeczy duchowe kochamy bardziej, sprawiedliwość jest kochana bardziej niż piękno zewnętrzne" ${ }^{37}$. Wewnętrzny człowiek,

32 Augustinus, De Trinitate 15, 7, 11, CC 50, s. 474, tł. M. Stokowska, Święty Augustyn, O Trójcy Świętej, Kraków 1996, s. 471.

33 Por. J. Patout Burns, Variations on a dualist theme: Augustine on the body and the soul, w: Interpreting tradition (the art of theological reflection), red. J. Kopas, California 1984, s. 18.

34 Por. Augustinus, Sermo 156, 14, 15, PL 38, 849.

35 Augustinus, Enarrationes in Psalmos 145, 5, CC 40, s. 2108, t1. J. Sulowski, Święty Augustyn, Objaśnienia Psalmów, PSP 42/1, Warszawa 1986, s. 305.

36 Por. J.-M. Fontanier, La beauté selon Saint Augustin, Rennes 2008, s. 86.

37 Augustinus, Sermo 159, 3, 3, PL 38, 869 (tł. własne). 
dusza ludzka, a więc także świat wewnętrznych wartości są ważniejsze niż to, co materialne i zewnętrzne. W komentarzu do psalmów Augustyn pokazuje etapy wstępowania ku temu, co większe. Pisze:

teraz spojrzyj na niebo i na ziemię. Nie na tyle podobają ci się piękne ciała, ażebyś dzięki nim pragnął się stać szczęśliwym. W umyśle znajduje się to, czego szukasz. Chcesz przecież być szczęśliwym; umysłem swoim szukaj to, co jest lepszego. Skoro są dwie istoty duch i ciało, wśród nich lepsze jest to, co nazywa się duchem. Ciało twoje może stać się lepsze przez to, co lepsze, ponieważ ono jest podległe duchowi. Zatem lepszym może stać się twoje ciało przez ducha, ponieważ kiedy duch twój będzie sprawiedliwy, to później nieśmiertelnym stanie się także twoje ciało. [...] Jeśli dla twojego ciała dobrem jest twój duch, jako że lepszy jest od twojego ciała; szukając twego dobra, szukaj go w tym, co jest lepsze dla twego ducha. [...] W duchu twoim jest obraz Boga, pojmuje to umysł ludzki. Przyjął go, ale skłaniając się do grzechu, uszkodziłeś go. Jego restaurator przyszedł sam, ten, który przedtem był sprawcą. Przecież przez Słowo wszystko się stało i przez Słowo został wyciśnięty ów obraz. [...] Pozostaje ci zatem, żebyś szukał tego, co lepsze od twego umysłu. Czym jest to, przysięgam, jeśli nie twój Bóg? Niczego lepszego nie znajdziesz, ponieważ kiedy natura twoja zostanie udoskonalona, zrówna się z aniołami. Wyżej jest jedynie Stwórca. Wznieś się do Niego, nie zniechęcaj się, nie mów: to za wiele dla mnie ${ }^{38}$.

Znaczenie duszy jest nierozerwalnie związane z obrazem Boga, jaki nosi w sobie człowiek ${ }^{39}$. Dusza jest częścią człowieka najbardziej bliską Bogu, duchową i najbardziej boską. Ona decyduje o wyjątkowości człowieka, w niej jest Boży obraz i ona daje człowiekowi możliwość odpo-

38 Augustinus, Enarrationes in Psalmos 32 (3), 16, CC 38, s. 453, tł. J. Sulowski, PSP 37, s. 315.

39 Por. Augustinus, De Trinitate 12, 11, 16, CC 50, s. 370: „Honor enim hominis verus est imago et similitudo Dei”. 
wiedzi na wezwanie Boga ${ }^{40}$. Myśl chrześcijańska uznaje, że obraz Boży znajduje się w duszy, a przede wszystkim w rozumie ${ }^{41}$. W Komentarzu do Pierwszego Listu św. Jana Augustyn pisał: „Gdzie człowiek został uczyniony na obraz Boga? W rozumie, w duchu, w człowieku wewnętrznym, w tym przez co ma intuicję prawdy, czym rozróżnia sprawiedliwość od niesprawiedliwości, wie przez kogo został uczyniony, może rozpoznać swojego Stwórcę i chwalić Go" ${ }^{42}$. Według Augustyna dusza przez kontemplację rzeczy stworzonych powinna się wznosić od rzeczywistości materialnych do duchowych i od czasowych do wiecznych ${ }^{43}$.

Dla Augustyna „osoba ludzka jest punktem odniesienia wszystkich wartości, chociaż nie jest ich źródłem"44. Aksjologia augustyńska posiada zawsze wymiar humanistyczny. Człowiek ma obowiązek szukania swego właściwego dobra. W komentarzu do psalmów znajdujemy słowa:

Szukaj swojego dobra, duszo! Dla każdego bytu istnieje osobne dobro: wszystkie stworzenia mają swoje własne dobro odpowiadające ich jedności i doskonałości ich natury. Najważniejsze jest to, co jest potrzebne każdemu bytowi niedoskonałemu, aby wydoskonalić się. Szukaj swojego dobra! Dlaczego Mnie pytasz o dobro? Jeden tylko jest Dobry (Mt 19, 17). Najwyższe dobro jest twoim dobrem ${ }^{45}$.

Dobrem człowieka jest dobro wyższe od tego, co materialne i zmysłowe, a więc dobro rozumne i duchowe, wzniosłe. Ostatecznie jest nim sam

40 Por. S.J. Duffy, Antropologia, w: Agostino. Dizionario enciclopedico, red. A.D. Fitzgerald - L. Alici - A. Pieretti, Roma 2007, s. 207.

41 Por. Augustinus, Enarrationes in Psalmos 32 (3), 16, CC 38, s. 453, tł. J. Sulowski, PSP 37, s. 315. Zob. G. Madec, Saint Augustin et la Philosophie. Notes critiques, Paris 1992, s. 86-93.

42 Augustinus, In epistulam Iohannis tractatus 8, 6, CSEL 25, s. 212, tł. W. Kania, Święty Augustyn, Homilie na Pierwszy List św. Jana, PSP 15/2, Warszawa 1977, s. 422.

43 Por. Augustinus, De vera religione 39, 72, CC 32, s. 234.

44 S. Kowalczyk, Człowiek i Bóg w nauce św. Augustyna, Warszawa 1987, s. 205.

45 Augustinus, Enarrationes in Psalmos 102, 8, CC 40, s. 1458, tł. J. Sulowski, Święty Augustyn, Objaśnienia Psalmów, PSP 40, Warszawa 1986, s. 382. 
Bóg jako Dobro Najwyższe. W augustyńskiej myśli odkrywa się Go przede wszystkim, wchodząc do własnego człowieka wewnętrznego i przekraczając duszę i rozum ku temu, co najwyższe, uniwersalne i obiektywne.

\section{Piękno i brzydota. Wewnętrzność w estetyce teologicznej}

Augustyn jest bez wątpienia ,wybitnym kontynuatorem wielkiej teorii piękna"46, na którą składa się myśl pitagorejczyków, platoników i stoików. Połączył teologię z estetyką. Tak jak Platon i wielu Ojców Kościoła zauważa, że nie tylko przedmioty są piękne, ale piękne są także cnoty. W wymiarze indywidualnym cnota jest pięknem duszy ${ }^{47}$. Istnieje piękno sprawiedliwości, rozwagi, miłości i pięknych obyczajów. Jest także piękno nauk i piękno uporządkowanej społeczności. Platon odróżnił prawdziwe piękno od pozornego piękna, piękno samo w sobie od piękna, które podoba się czy wydaje się piękne ${ }^{48}$. Chce on dotrzeć do piękna źródłowego, które jest pięknem samym w sobie. Według Augustyna rzeczy są piękne, jeśli są odpowiednie do możliwości poznawczych człowieka, jeśli sięgają jego głębi. Nieodpowiedniość jest brzydka. Piękne więc jest to, co porusza rozumną i duchową sferę człowieka.

W Augustyńskiej wizji w estetyce podobnie jak w innych dziedzinach niezbędne jest wędrowanie od niższych stopni piękna ku wyższym, aby dojść do piękna samego w sobie. Poprzez piękno niższe człowiek idzie do piękna źródłowego, które jest ostateczną miarą wszystkiego, co piękne. W dialogu De ordine twierdzi, że wszelkie piękno jest naśladowaniem Najwyższego Piękna, a niższe piękno w porównaniu z nim ,jest szpetotą"49. W zestawieniu z Bogiem wszystko jest mniej zachwycające. Piękno nie ma więc charakteru wrażeniowego, ale przede wszystkim

\footnotetext{
6 Cz.S. Bartnik, Personalizm, Lublin 2000, s. 438.

47 Por. W. Tatarkiewicz, Historia estetyki, t. 1, Warszawa 2009, s. 132.

48 Por. Tatarkiewicz, Historia estetyki, t. 1, s. 133-135.

49 Augustinus, De ordine 2, 19, 51, CC 29, s. 118.
} 
posiada charakter relacyjny. Piękne jest to, co jest odpowiednie do podmiotu poznającego, ale także odpowiednie do piękna, które jest jego źródłem i miarą. Bardzo dobrze oddaje tę myśl sposób podejścia Augustyna do Chrystusa cierpiącego na krzyżu. Tutaj objawia się On ludziom jako nieposiadający wdzięku ani blasku, po prostu brzydki tak, że nie można na niego patrzeć (Iz 53,2). Na krzyżu stracił całe piękno zewnętrzne. W takim razie hellenistyczna filozofia piękna została zakwestionowana ${ }^{50}$. Dla Augustyna w Chrystusie umęczonym jednak znajduje swój wyraz najwyższe piękno ${ }^{51}$. Jaśnieje w Nim piękno Boga, który kocha miłością ofiarną. Zewnętrzne piękno jest przemijające i złudne, często także egoistyczne, staje się tłem, kontrastem do piękna wewnętrznego, ukrytego dla oczu. To miłość Boga posiada piękno przewyższające wszelkie inne ${ }^{52}$. Augustyn zauważa, że na ziemi piękno niesie w sobie pewien paradoks. Jest ukryte w zalążku, w tym, co namacalne, jak ziarno. Chrystus na krzyżu jest paradygmatem i największą manifestacją piękna. Boska natura w Chrystusie sprawia, że jest On zawsze, także na krzyżu, choć zdeformowany, „najpiękniejszym z synów ludzkich”, jak to zapowiada prorocki Ps 45. Chrystus jako Bóg stworzył rzeczy piękne ${ }^{53}$ i jest pięknem samym w sobie, ale ze względu na ludzi na chwilę, zewnętrznie, przestał być piękny, tzn. ukrył swoje piękno. Jednak w swojej naturze boskiej nie przestał być piękny, ale dla zbawienia ludzi, jako człowiek, z miłości poddał się cierpieniu i śmierci ${ }^{54}$. Jego piękno wewnętrzne wcześniej jest widoczne w cnotach, w sprawiedliwości, mądrości, pokorze i w posłuszeństwie Ojcu. Brzydota Chrystusa na krzyżu jest pozorna, trzeba ją przekroczyć, aby dotrzeć do wewnętrznego, niewidzialnego piękna. Dla tych, którzy Go miłują, jest jasne, że to nie osobisty grzech uczynił Go zdeformowa-

\footnotetext{
50 J. Ratzinger, $W$ drodze do Jezusa Chrystusa, Kraków 2004, s. 34.

51 Por. J. Ratzinger, Presentazione, w: Dio e il bello in sant'Agostino, red. J. Tscholl, Milano 1996, s. 7.

52 Por. Ratzinger, Presentazione, s.7.

53 Por. Augustinus, Sermo 138, 6, PL 38, 769.

54 Por. Augustinus, Enarrationes in Psalmos 103 (1), 3, CC 40, s. 1476.
} 
nym, ale uniżenie i ofiarna miłośćc ${ }^{55}$. On zawsze jest piękny ${ }^{56}$. „On jest piękniejszy niż synowie ludzcy, trzeba tę urodę tym bardziej podziwiać i kochać im mniej ma ona wspólnego z pięknem ciała"57. Im bardziej objawia się jako zdeformowany, tym bardziej widać Jego piękną miłość. Chrześcijanin kocha Go nie jako słodycz dla ciała, ale, jak to mówi Pieśń nad Pieśniami, jako słodycz dla duszy ${ }^{58}$. Tu objawia się niezwykłość i waga przekroczenia tego, co zewnętrzne, aby dojść do wewnętrzności. W Chrystusie nie kocha się przybitych rąk i nóg, ubiczowanych pleców i zmasakrowanego ciała ani przebitego boku, ale miłość, która przez to ciało się wyraża ${ }^{59}$. Według Augustyna tu objawia się najgłębsza prawda o życiu i tajemnicy piękna. Chrystus „opluty, upokorzony, ubiczowany, poraniony i ukrzyżowany i w oczach świata bezwartościowy” jednak „rozbłyska chwałą"60. W Nim jest miłość bezinteresowna i radykalna, bo „umarł za niesprawiedliwych, piękny za brzydkich”61.

W takiej estetyce kluczem jest niewidoczna treść i ukryta głębia, którą trzeba odkryć, przekraczając to, co materialne. Chrystus na krzyżu nie posiadał formy ani piękna zewnętrznego, objawił swoją śmiertelność, aby dać człowiekowi pierwotną formę i pierwotne piękno Boże, które ten po grzechu utracił, ale ciągle nieświadomie pragnął i szukał w zewnętrznych rzeczach tego świata. Cierpienie Chrystusa i Jego deformacja na krzyżu przede wszystkim są znakiem i objawieniem Jego miłości62. Według Augustyna w Ukrzyżowanym ten, kto jest zdolny sięgnąć głębiej, znajduje syntezę piękna, dobra i prawdy ${ }^{63}$.

\footnotetext{
55 Por. Augustinus, De sancta virginitate 37, 38, CSEL 41, s. 273.

56 Por. Augustinus, Enarrationes in Psalmos 44, 3, CC 38, s. 498.

57 Augustinus, De civitae Dei 17, 16, CC 48, s. 595, tł. W. Kubicki, s. 674.

58 Pnp 1,6. Por. Augustinus, Sermo 138, 6, PL 38, 769.

59 Por. Augustinus, Enarrationes in Psalmos 127, 8, CC 40, s. 1872.

60 Augustinus, Sermo 44, 2, CC 103, s. 584.

61 Por. Augustinus, In epistulam Iohannis tractatus 9, 9, CSEL 25, s. 245.

62 Por. C. Harrison, Beauty and Revelation in Thought of Saint Augustine, Oxford 1992, s. 235.
}

63 Por. J. Szymik, Theologia Benedicta, t. 1, Katowice 2010, s. 101. 


\section{Bóg i czlowiek. Wewnętrzność w chrystologii}

Augustyn zauważa, że tajemnica wcielenia odpowiada formie ludzkiego poznania. Cała ekonomia zbawienia, w tym wcielenie i rzeczywistość Nowego Przymierza, dostosowuje się do stanu zewnętrzności i czasowości, w którym znajduje się człowiek. W ten sposób Bóg chce doprowadzić człowieka uwikłanego w materialność do własnej wewnętrzności i wieczności ${ }^{64}$.

We wcieleniu Augustyn odkrywa jedność i harmonię między Bogiem i człowiekiem. Jest to jedność i harmonia zarówno doskonała, jak i paradoksalna, nie do pomyślenia dla filozofów starożytnych. J.-M. Fontanier zauważa, że można mówić o trzech poziomach tej jedności i harmonii. Najpierw istnieje harmonia $\mathrm{w}$ dwóch naturach zjednoczonych w jednej osobie wcielonego Słowa, następnie w jedynej śmierci Chrystusa, która ocala człowieka od śmierci duchowej i śmierci wiecznej, oraz jedności Kościoła, który Augustyn nazywa całym Chrystusem (totus Christus) ${ }^{65}$.

We wcieleniu Chrystus łączy się z każdym człowiekiem, adaptuje się do sytuacji człowieka, a czyni to także przez mękę i śmierć. Chce $\mathrm{W}$ ten sposób pociągnąć człowieka do miłości piękna wewnętrznego ${ }^{66}$. We wcieleniu Syn Boży zbudował sobie na ziemi ,skromny dom” i przywdział „tunikę ludzkiej skóry”, aby człowiek został uzdrowiony i nakarmiony miłością, a w ostateczności przeniesiony do Bożego świata ${ }^{67}$.

Mówiąc o człowieczeństwie i bóstwie Chrystusa, Augustyn lubi odwoływać się do Pawłowego hymnu chrystologicznego z Listu do Filipian (Flp 2,6-11) ${ }^{68}$. Podkreśla, że forma servi i forma Dei współistnieją ze sobą

64 Por. G. Madec, La Patrie et la voie. Le Christ dans la vie et la pensée de Saint Augustin, Paris 1989, s. 59-67.

65 Por. J.-M. Fontanier, La beauté selon Saint Augustin, Rennes 2008, s. 162.

66 Por. De Trinitate 4, 2, 4, CC 50, s. 164. Zob. É. Bailleux, La Christologie de saint Augustin dans le „De Trinitate”, RechAug 7 (1971) s. 223.

67 Por. Augustinus, Confessiones 7, 18, 24, CSEL 33/1, s. 164.

68 Por. A. Verwilghen, Christologie et spiritualité selon saint Augustin. L'hymne aux Philippiens, Paris 1985, s. 598. 
w Słowie wcielonym, przy czym forma Dei identyfikuje się z Bogiem, jest właściwa Synowi, wyraża Jego naturę Boską i doskonały obraz Boga, forma servi natomiast identyfikuje się z człowieczeństwem ${ }^{69}$. Hans Urs von Balthasar, idąc za Augustynem, będzie mówił o „ukrytości” Bożej chwały w Chrystusie ${ }^{70}$. W godzinie Chrystusa Jego piękno jest ukryte in forma servi, popaschalne piękno Chrystusa natomiast objawia się polimorficznie: w Kościele, w Eucharystii, w Słowie Bożym. Historia teologii mówi, że istnieje Christus multiformis ${ }^{71}$. Przez zewnętrzne formy człowieczeństwa, Eucharystii, Kościoła trzeba przez wiarę odkryć Chrystusa in forma Dei.

W komentarzu do Ps 103 Augustyn zauważa pozorną sprzeczność bóstwa i człowieczeństwa w Chrystusie. Odwołując się znowu do wspomnianego hymnu chrystologicznego (Flp 2,6-7), mówi o Oblubieńcu pełnym blasku, który chce swojej oblubienicy, tzn. grzesznej ludzkości, ofiarować piękno. Aby wydobyć umiłowaną z brzydoty grzechu, sam siebie czyni brzydkim in forma servi i prowadzi do swojego boskiego świata, którego przecież nigdy nie stracił in forma $D e i^{72}$.

W chrystologii Augustyn na różny sposób pokazuje połącznie człowieczeństwa i bóstwa w osobie Zbawiciela. Używa ewangelicznego obrazu drogi, (,Ja jestem drogą" - J 14,6), którego dopełnieniem jest obraz ojczyzny, w ten sposób obydwa odnoszą się odpowiednio właśnie do człowieczeństwa, które jest drogą, i do bóstwa, które jest ojczyzną ${ }^{73}$. Jezus Chrystus jako wcielony Syn Boży posiada więc podwójną funk-

69 Por. T.-J. Van Bavel, Recherches sur la christologie de saint Augustin: l'humain et le divin dans le Christ d'après saint Augustin, Fribourg 1954, s. 46.

70 Por. H.U. von Balthasar, Chwała. Estetyka teologiczna, t. 3: Teologia, cz. 2: Nowy Testament, Kraków 2010, s. 258.

71 Por. K. Klauza, Teokalia. Piękno Boga. Prolegomena do estetyki teologicznej, Lublin 2008, s. 43.

72 Por. Augustinus, Enarrationes in Psalmos 103 (1), 4-5, CC 40, s. 1476-1477.

73 Por. Augustinus, Sermo 91, 7, PL 38, 571; Augustinus, Sermo 92, 3, PL 38, 573. Por. L. Galati, Cristo la Via nel pensiero di S. Agostino, Roma, 1956. Zob. G. Madec, La Patrie et la voie. Le Christ dans la vie et la pensée de Saint Augustin, Paris, 1989. 
cję: ojczyzny i drogi. Z jednej strony konstytuuje On cel ludzkiej egzystencji $^{74}, \mathrm{z}$ drugiej jest również środkiem, który prowadzi do tego celu. W tych obydwu wymiarach i funkcjach Chrystus objawia równocześnie prawdę o wieczności i o czasie oraz o moście je łączącym. „Skierujmy nasze serca ku Chrystusowi. Wpatrzeni w Niego nie zbłądzimy. On bowiem jest prawdą, do której spieszymy. On drogą, po której idziemy"75 mówi biskup Hippony do wiernych. Chrystus jako Bóg i jako człowiek jest pośrednikiem prowadzącym ku jedności. W sobie samym uczynił On wszystkich jednością z Bogiem ${ }^{76}$, jak napisze Augustyn, po to, abyśmy „złączyli się z Jednym, cieszyli się Jednym i trwali w jedności"77, uczestnicząc w jednej miłości i jednej chwale. Chrystus konstytuuje w sobie drogę, którą ludzkość jest niesiona w wewnętrzne życie Trójcy Świętej. Tą drogą, przez Niego, spływa ku całej ludzkości Boża łaska.

\section{Podsumowanie}

Zasadniczo Augustyn zagadnieniem wewnętrzności zajmuje się bezpośrednio w antropologii i teorii poznania, ale jest ono obecne jako instrument w retoryce i teorii znaków, w egzegezie i rozważaniach o pięknie, w chrystologii, mariologii, sakramentologii. Zasada wewnętrzności nie pozwala Augustynowi pozostać na poziomie wrażeń i zewnętrznych form, ale zawsze każe mu szukać głębi, iść wzwyż i wydobywać rzeczy duchowe oraz ukryte. Jest to droga od wiedzy do mądrości. Zasada wewnętrzności nie pozwala mu zostać na powierzchni zagadnień i inspiruje

\footnotetext{
74 Por. Augustinus, Enarrationes in Psalmos 149, 1, CC 40, s. 2178.

75 Augustinus, Enarrationes in Psalmos 84, 2, CC 39, s. 1162, tł. J. Sulowski, PSP 40, s. 73 .

76 Por. A. Trapé, Introduzione, w: Sant'Agostino, La Trinià, NBA IV XLIV.

77 Augustinus, De Trinitate 4, 7, 11, CC 50, s. 176, tł. M. Stokowska, Święty Augustyn, O Trójcy Świętej, Kraków 1996, 165: „In quo nunc per fidem mundati et tunc per speciem redintegrati et per Mediatorem Deo haereamus uni, fruamur uno, permaneamus unum".
} 
do głębszych poszukiwań. W metafizyce Augustyn podkreśla, że każdy byt jest tym, czym jest przez swoją formę, która jest czymś w rodzaju wewnętrznego kształtu. Treść zawsze posiada więc jakąś formę, jakiś kształt. O ile treść jest wewnętrzna, o tyle kształt jest jakąś jej zewnętrznością, nawet niekoniecznie rozumianą tylko w kategoriach wymiernych i dotykalnych zmysłami. To, co wewnętrzne, okazuje się ważniejsze od zewnętrznych form, chociaż ich potrzebuje. W retoryce sztuka mówienia, dobierania słów i figur nie jest ważniejsza od podjętego argumentu. Tak pozostanie w każdej dziedzinie ludzkiej wiedzy.

W antropologii Augustyn będzie podkreślał, że człowiek to wyjątkowe i jedyne połączenie duszy oraz ciała. W tym złożeniu ciało samo w sobie jest dobre, ale to dusza powinna rządzić ciałem. Estetyka teologiczna Augustyna pokazuje, że zewnętrzna forma może budować świat pozorów, a każde piękno odsyła do swojego piękna źródłowego, człowiek natomiast jest wezwany, aby nie pozostawać na powierzchni rzeczywistości, ale wstępować od rzeczy cielesnych do duchowych. W chrystologii zasada wewnętrzności każe Augustynowi szukać w Chrystusie umęczonym na krzyżu ukrytej chwały, więc w uniżonej we wcieleniu i na krzyżu postaci sługi każe dostrzec niezmienną postać Bożą. Poszukiwanie tego, co wewnętrzne, staje się augustyńską metodą do odkrywania rzeczywistości i jej głębszych wymiarów. Jest sposobem wstępowania wzwyż, ku temu, co najwyższe.

\section{The Principle of Interiority in the Thought of Saint Augustine}

(summary)

The article presents the place of the principle of internality in the thought of Saint Augustine. He borrowed it from ancient philosophical thought and made it so that it became fundamental to his philosophy. The principle finds its application in rhetoric and sign theory, but also in metaphysics and the theory of knowledge. It becomes a method of discovering deeper levels of being. It is important in anthropology and here is a way of finding God, who is deeper than what is deepest in man and higher than what is highest in man. The article shows the path of Augustinian aesthetic experience in which one moves from material to spiritual things and ultimately is led to the source beauty. The principle 
of interiority has its application in Christology, allows us to find hidden glory and an unchanging deity in the suffering Christ.

Keywords: Augustine of Hippo; interiority; rhetoric; theological esthetics; Christology

\section{Zasada wewnętrzności w myśli świętego Augustyna}

(streszczenie)

Artykuł prezentuje miejsce zasady wewnętrzności w myśli św. Augustyna. Zapożyczył on ją ze starożytnej myśli filozoficznej i uczynił swoją tak, że stała się fundamentalna dla jego filozofii. Zasada znajduje swoje zastosowania w retoryce i teorii znaku, ale także w metafizyce i teorii poznania. Staje się metodą odkrywania głębszych pokładów bytu. Jest ważna $\mathrm{w}$ antropologii i tu jest sposobem dotarcia do odkrycia Boga, który jest głębszy niż to, co w człowieku najgłębsze, i wyższy od tego, co w człowieku najwyższe. Artykuł pokazuje drogę Augustyńskiego doświadczenia estetycznego, w którym przechodzi się do rzeczy cielesnych do niecielesnych i ostatecznie ku pięknu źródłowemu. Zasada wewnętrzności ma swoje zastosowanie w chrystologii, gdzie w cierpiącym Chrystusie każe szukać ukrytej chwały i niezmiennego bóstwa.

Słowa kluczowe: Augustyn z Hippony; wewnętrzność; retoryka; estetyka teologiczna; chrystologia

\section{Bibliografia \\ Źródła}

Augustinus, Confessiones, CSEL 33/1, tł. J. Kubiak, Święty Augustyn, Wyznania, Warszawa 1987.

Augustinus, Contra academicos, CC 29, s. 3-61, tł. K. Augustyniak, Augustyn, Przeciw akademikom, w: Św. Augustyn, Dialogi filozoficzne, Kraków 1999, s. 57-150.

Augustinus, De beata vita, CC 29, s. 65-85, tł. A. Świderkówna, Augustyn, O życiu szczęśliwym, w: Św. Augustyn, Dialogi filozoficzne, Kraków 1999, s. 15-50.

Augustinus, De civitate Dei, CC 47, s. 1-314 (ks. 1-10); CC 48, s. 321-866 (ks. 11-22), tł. W. Kubicki, Święty Augustyn, Państwo Boże, Kęty 1998.

Augustinus, De doctrina cristiana, CC 32, s. 1-167, tł. J. Sulowski, Święty Augustyn, O nauce chrześcijańskiej, Warszawa 1989.

Augustinus, De libero arbitrio, CC 29, s. 211-321, tł. A. Trombala, Augustyn, $O$ wolnej woli, w: Św. Augustyn, Dialogi filozoficzne, Kraków 1999, s. 493-650. 
Augustinus, De magistro, CC 29, s. 157-203, tł. J. Modrzejewski, Augustyn, O nauczycielu, w: Św. Augustyn, Dialogi filozoficzne, Kraków 1999, s. 433-486.

Augustinus, De musica, PL 32, 1081-1194, tł. L. Witkowski, Augustyn, Traktat o muzyce, Lublin 1999.

Augustinus, De natura boni, CSEL 25/2, s. 853-889, tł. M. Maykowska, Augustyn, O naturze dobra, w: Św. Augustyn, Dialogi filozoficzne, Kraków 1999, s. 829-864.

Augustinus, De natura et gratia, CSEL 60, s. 231-299.

Augustinus, De ordine, CSEL 63, s. 121-185, tł. J. Modrzejewski, Augustyn, O porzadku, w: Św. Augustyn, Dialogi filozoficzne, Kraków 1999, s. 155-233.

Augustinus, De sancta virginitate, CSEL 41, s. 233-302, tł. P. Nehring, Augustyn, O świętym dziewictwie, ŹM 27, Kraków 2002, s. 271-348.

Augustinus, De Trinitate, CC 50, s. 25-380 (ks. 1-12); CC 50/A, s. 381-535 (ks. 13-15), tł. M. Stokowska, O Trójcy Świętej, Kraków 1996.

Augustinus, De vera religione, CC 32, s. 187-260, tł. J. Ptaszyński, Augustyn, O prawdziwej wierze, w: Św. Augustyn, Dialogi filozoficzne, Kraków 1999, s. 733-818.

Augustinus, Enarrationes in Psalmos, CC 38, s. 1-616 (Ps 1-50); CC 39, s. 623-1417 (Ps 51-100); CC 40, s. 1425-2196 (Ps 101-150), tł. J. Sulowski, Święty Augustyn, Objaśnienia Psalmów, PSP 37 (Ps 1-36); PSP 38 (Ps 37-57); PSP 39 (Ps 58-77); PSP 40 (Ps 78-102); PSP 41 (Ps 103-123); PSP 42/1 (Ps 124-150), Warszawa 1986.

Augustinus, In epistulam Iohannis tractatus, CSEL 25, s. 193-248, tł. W. Kania, Święty Augustyn, Homilie na Pierwszy List św. Jana, PSP 15/2, Warszawa 1977, s. 381-502.

Augustinus, Retractationes, CSEL 36, s. 1-204, tł. J. Sulowski, Augustyn, Sprostowania, PSP 22, Warszawa 1979, s. 181-287.

Augustinus, Sermones, PL 38, 23-1484; PL 39, 1493-1638; PLS 2, t1. W. Eborowicz, Augustyn, Wybór kazań, Poznań 1936; tł. J. Jaworski, Wybór mów, PSP 12, Warszawa 1973; t1. M. Saks - S. Rączka, Augustyn, Mowa XVI, „Vox Patrum” 10 (1986) s. 345-348; tł. F. Małaszyński, Augustyn, Mowa 104. Traktat o Marcie i Marii, które oznaczaja dwa rodzaje życia, w: Homo meditans, t. 2: Kontemplacja i działanie, red. W. Słomka, Lublin 1984, s. 175-180; tł. W. Eborowicz, Augustyn, Mowa 221. O Świętej Nocy, w: Kazania i homilie na święta Pańskie i Maryjne, red. L. Gładyszewski, Lublin 1976, s. 189-187.

Rhetorica ad Herennium. De ratione dicendi ad C. Herennium libri IV, ed. F. Marx, Lipsk, 1923.

Quintilianus, Institutio oratoria, Cambridge 1920. 


\section{Opracowania}

Balthasar von H.U., Chwała. Estetyka teologiczna, t. 2: Modele teologiczne, Cz. 1: Od Ireneusza do Bonawentury, Kraków 2007.

Balthasar von H.U., Chwała. Estetyka teologiczna, t. 3: Teologia, cz.2: Nowy Testament, Kraków 2010.

Bartnik Cz.S., Personalizm, Lublin 2000.

Bavel van T.-J., Recherches sur la christologie de saint Augustin: l'humain et le divin dans le Christ d'après saint Augustin, Fribourg 1954.

Cary Ph., Interiorità, w: Agostino. Dizionario enciclopedico, red. A.D. Fitzgerald L. Alici - A. Pieretti, Roma 2007, s. 844-846.

Chapman E., Saint Augustine's Philosophy of Beauty, New York - London 1939.

Cipriani N., Retorica, w: Agostino. Dizionario enciclopedico, red. A.D. Fitzgerald L. Alici - A. Pieretti, Roma 2007, s. 1204.

Curtone E.J., Sacramenti, w: Agostino. Dizionario enciclopedico, red. A.D. Fitzgerald - L. Alici - A. Pieretti, Roma 2007, s. 1232-1240.

Doull J.A., Qui es la sapientia augustiniana, AugM 36 (1991) s. 81-88.

Duffy S.J., Antropologia, w: Agostino. Dizionario enciclopedico, red. A.D. Fitzgerald L. Alici - A. Pieretti, Roma 2007, s. 202-215.

Fontanier J.-M., La beauté selon Saint Augustin, Rennes 2008.

Galati L., Cristo la Via nel pensiero di S. Agostino, Roma, 1956.

Harrison C., Beauty and Revelation in Thought of Saint Augustine, Oxford 1992.

Klauza K., Teokalia. Piękno Boga. Prolegomena do estetyki teologicznej, Lublin 2008.

Kowalczyk S., Człowiek i Bóg w nauce św. Augustyna, Warszawa 1987.

Madec G., Christus, scientia et sapientia nostra. Le principe de cohérence de la doctrine augustinienne, RAug 10 (1975) s. 77-85.

Madec G., La Patrie et la voie. Le Christ dans la vie et la pensée de Saint Augustin, Paris 1989.

Mortara Garavelli B., Manuale di retorica, Milano 1988. 
Patout Burns J.J., Variations on a dualist theme: Augustine on the body and the soul, $\mathrm{w}$ : Interpreting tradition (the art of theological reflection), red. J. Kopas, California 1984, s. 13-26.

Ratzinger J., Presentazione, w: J. Tscholl, Dio e il bello in sant'Agostino, Milano 1996, s. 5-7.

Ratzinger J., W drodze do Jezusa Chrystusa, Kraków 2004.

Szymik J., Theologia Benedicta, t. 1, Katowice 2010.

Tatarkiewicz W., Historia estetyki, t. 1, Warszawa 2009.

Trapè A., Introduzione, w: Sant'Agostino, La Trinià, NBA IV VII-LXV.

Trapè A., Sant'Agostino, w: Patrologia, t. 3, red. A. di Berardino, Marietti 1978, s. 323-434.

Tscholl J., Dio e il bello in sant'Agostino, Milano 1996.

Verwilghen A., Christologie et spiritualité selon saint Augustin. L'hymne aux Philippiens, Paris 1985. 